\title{
Stock Market Performance, the Exchange Rate, and the Brazilian Economy
}

\author{
Michael C. Budden \\ Department of Marketing and Supply Chain Management, Southeastern Louisiana University \\ SLU 10844, Hammond, LA 70402, USA
}

Tel: 1-985-549-2277_E-mail: mbudden@selu.edu

Robert F. Cope III

Department of Marketing and Supply Chain Management, Southeastern Louisiana University SLU 10844, Hammond, LA 70402, USA

Tel: 1-985-549-2277Ｅ-mail: robert.cope@selu.edu

\section{Yu Hsing}

Department of Management and Business Administration, Southeastern Louisiana University SLU 10813, Hammond, LA 70402, USA

Tel: 1-985-549-2086Ｅ-mail: yhsing@selu.edu

Susan M. L. Zee (Corresponding author)

Department of Marketing and Supply Chain Management, Southeastern Louisiana University

SLU 10844, Hammond, LA 70402, USA

Tel: 1-985-549-2277Ｅ-mail: susan.zee@selu.edu

\begin{abstract}
Incorporating the goods market equilibrium, an interest-rate rule, and aggregate supply and applying a generalized least squares (GLS) method, this analysis finds a higher real stock price, real appreciation of the Brazilian "real," increased government deficit as a percent of GDP, increased U.S. output, or a lower real federal funds rate would raise Brazil's real GDP. Thus, maintaining a robust stock market or pursuing real appreciation would help stimulate the Brazilian economy. Brazil's real output will benefit from an economic recovery in the U.S. and monetary easing by the Federal Reserve Bank.
\end{abstract}

Keywords: Stock market performance, Exchange rate, Inflation targeting, Budget deficits 


\section{Introduction}

As one of the BRIC countries, Brazil has experienced business and economic slowdowns due to the global financial crisis. During 2008.Q3-2009.Q1, its real GDP, household consumption spending, and gross fixed capital formation declined 9.23\%, 2.80\%, and 25.54\%, respectively. During the same period, its balance of trade changed from a surplus of 4.214 billion reais to a deficit of 3.781 billion reais. (International Financial Statistics, International Monetary Fund, April 2010). The Brazilian stock market has experienced wide swings. Its Bovespa stock index plunged 59.96\% from a high of 73,517 on May 20, 2008 to a low of 29,435 in October 2008. After that, the index rose $143.88 \%$ to 71,785 on April 8, 2010 and then declined 16.06\% to 60,259 on May 21, 2010 (Bloomberg.com). The exchange rate of the Brazilian real against the U.S. dollar (BRL/USD) depreciated 68.08\% from 1.558 on August 1, 2008 to 2.6187 on December 5, 2008. Since then, the Brazilian real has shown a trend of appreciation, and the BRL/USD exchange rate reached 1.8484 on May 21, 2010 (Federal Reserve Bank of St. Louis; The Wall Street Journal).

Brazil has recovered from the economic slowdown faster than most other Latin American countries mainly due to strong domestic demand, diversification of trading partners and the economic structure, a sound financial system, tax breaks for selected consumer durable goods, effective monetary and fiscal policies, increased credit availability to households and firms, relatively low interest rates, a relatively low cost of a stimulus package equal to $1 \%-1.5 \%$ of GDP, a flexible exchange rate that responds to external shocks, and a relatively low ratio of government debt to GDP, etc. (The Economist, September 12, 2009; International Monetary Fund, 2009).

In the economic recovery process, Brazil faces some concerns (The Economist, October 15, 2009; Stewart, Lyons, and Wessel, 2010; Stewart and Jeffris, 2010). First, the Brazilian real has recently become relatively strong from a low of 3.7966 Brazilian reais per U.S. dollar in October 2002 to a high of 1.7568 in April 2010, causing exported goods to be too expensive to compete in the global market, but reducing prices of imported goods and easing domestic inflation. Second, the central bank of Brazil raised its policy interest rate by 75 basis points from $8.75 \%$ to $9.50 \%$, which is relatively high based on the world standard. As recovery continues, the policy interest rate may need to be raised again in order to pursue the targeted inflation rate. Third, Brazil continues to face current-account deficits, which need to be financed by foreign capital inflows. The authorities are concerned about wrong type of speculative foreign capital, may flee Brazil during a financial crisis.

This analysis examines whether stock market performance, the exchange rate, and other relevant variables would affect real output in Brazil. Brazil is selected as a case study mainly because it the largest country in Latin America, a major trading partner with the U.S., and one of the major emerging economies. Empirical results may have policy implications and applicability to other Latin American countries. This paper has several focuses. First, a model is formulated based on the goods market equilibrium, an interest-rate rule, and an aggregate supply function. Second, in the interest-rate rule, monetary policy of the central bank would respond to the inflation gap, the output gap, the exchange rate, and the world interest rate. 
Third, the generalized least squares (GLS) method is applied in empirical work in order to correct for any violation of classical properties of the error terms.

\section{Literature Review}

There are several recent articles studying the stock market, the exchange rate, and other relevant subjects for Brazil and neighboring countries. Tabak (2003) shows that the random walk hypothesis for the Brazilian stock market is rejected before 1994 and is confirmed after 1994 mainly due to the easing of foreign capital controls. Worthington and Higgs (2003) test the weak-form market efficiency hypothesis for Brazil and six other Latin American countries. Based on multiple variance ratio and unit root tests, they find lack of support for the hypothesis. Guttler, Meurer, and Da Silva (2008) reveal that the stock market in Brazil is not efficient. These results suggest that stock market prices may move with trends and that future stock prices may be predicted by past stock values to some extent.

Canarella and Pollard (2007) reveal high volatility of the stock market in Brazil and the other five Latin American countries is either due to local crises, such as the 1998-1999 currency crisis, or global crises, but is transitory, lasting about 2-4 months. Diamandis (2008) analyzes whether the relationship between the stock markets in Brazil, three other Latin American countries, and the U.S. may have changed during 1988-2006. He indicates that short-run interdependence during the 1997-1998 financial crisis increases and then returns to their initial levels, and detects a significant volatility increase during the financial crisis for the stock markets in Brazil, Argentina, Chile, and Mexico.

Gomes and Paz (2005) examine the effect of real depreciation on the balance of trade for Brazil during 1990-1998 and find that there is evidence of a J-curve. In addition, there is evidence to show that the Marshall-Lerner condition holds, suggesting that real depreciation would deteriorate the trade balance initially and improve the trade balance in the long run. Hsing (2008) analyzes the impacts of real depreciation, real income in the home country, and real income the U.S. on the trade balance for Brazil and six other Latin American countries. For Brazil, he reports that real depreciation and the trade balance do not exhibit a J-curve effect, a higher real income in Brazil improves the trade balance, and a higher real income in the U.S. deteriorates the trade balance. Kalyoncu, et al. (2009) study the effect of real depreciation on the trade balance for Brazil and three other Latin American countries. For Brazil, they indicate that there is no cointegration relationship between real deprecation and the trade balance and that there is lack of evidence of a J-curve. Lyons (2010) analyzes the issue of the much-overvalued Brazilian real. The strong real is attributable to a relatively high overnight interest rate of $10.75 \%$ kept by the Central Bank of Brazil to contain inflation, to pay for huge trade deficits, and to attract foreign capital. However, this high interest rate has been used as carry trade by international investors to make profits. The high interest rate has hit the manufacturing sector hard, hurt exports, and reduced its global competitiveness.

Barbosa-Filho (2008) indicates that inflation targeting in Brazil has reduced inflation since the currency crises of 1999-2002, has reduced output growth and its volatility, and reduced the real interest rate, which led to a lower cost of borrowing and more incentive for households and firms to spend. Cerisola and Gelos (2009) find that inflation targeting in 
Brazil has helped secure inflation expectations and reduced its dispersion.

Rathbone (2010) examines the Brazilian economic situation. Among the strengths are less exposure to sub-prime loans, a relatively low foreign debt/GDP ratio, strong retail sales and internal demand, rising bank credit, declining poverty due to social policies, a low unemployment rate, an annual economic growth rate of $8 \%$ to $10 \%$, government anti-inflation policy, and the world $4^{\text {th }}$ largest auto market. Among the weaknesses are a rising inflation rate above the $4.5 \%$ inflation target, large current account deficits, a high benchmark interest rate of $12 \%$, and a strong real that hurts exports and domestic manufacturing. Reducing government spending would be needed to cool down the economy. Adrogué, Cerisola and Gelos (2010) show that several reforms and macroeconomic stability have raised Brazil's economic growth whereas several structural weaknesses such as persistent decrease in public investment in infrastructure, steady increase in government spending and external financial conditions have continued to exert negative impacts on Brazil's economic growth. They also recommend a reduction in government consumption spending in order to lower the real interest rate and promote economic growth.

So far, many previous works have made contributions to the understanding of the stock market behavior, the impact of real depreciation on the trade balance, and inflation targeting. This analysis extends previous works, formulates an open-economy macroeconomic model, and attempts to empirically estimate whether and how stock prices, exchange rates, and other relevant variables affect real output.

\section{The Model}

Extending Romer (2006), the model specifies aggregate spending as a function of real GDP, government spending, government revenues, the real interest rate, the real stock price, the real exchange rate, and world output. The real interest rate is determined by the inflation gap, the output gap, the real exchange rate, and the world real interest rate. The inflation rate is affected by the expected inflation rate, the output gap, and the real exchange rate. Consider a situation where there is equilibrium in the goods market and the target inflation rate and potential real GDP do not vary in the short run. Solving for real GDP, the real interest rate, and the inflation rate simultaneously, and treating other variables as exogenous, one can write the equilibrium real GDP as:

$\overline{R G D P}=Z(S T P, E X C, G E X, G R V, E I N, W O, W R)$

where

\footnotetext{
$\overline{R G D P}=$ equilibrium real GDP in Brazil,

STP = the real stock price index,

$\mathrm{EXC}=$ the real BRL/USD exchange rate,

GEX = central government spending,

GRV = central government revenues,

EIN = the expected inflation rate.
} 
WO = world output, and

$\mathrm{WR}=$ the world real interest rate.

GEX and GRV are combined into a new variable called the government deficit (DEF) and results in the following regression:

$$
\begin{aligned}
& \overline{R G D P}=\alpha_{0}+\alpha_{1} S T P+\alpha_{2} E X C+\alpha_{3} D E F+\alpha_{4} E I N+\alpha_{5} W O+\alpha_{6} W R+\mu \\
& +\quad \text { ? } \quad+\quad-\quad+\quad+\quad-
\end{aligned}
$$

where $\mu$ is the error term. It is expected the coefficients for STP, DEF, and WO are positive and the coefficients for EIN and WR are negative. Note the sign of the coefficient for EXC is ambiguous due to three different effects. When there is real depreciation, exports would rise, imports would decline, and net exports would improve. Real depreciation of the Brazilian real may cause the central bank of Brazil to raise the real interest rate to stabilize the exchange rate. A higher real interest rate would hurt domestic spending. Real depreciation of the Brazilian real may lead to higher import prices and higher inflation, which would cause the central bank of Brazil to raise the real interest rate to contain inflation. Hence, the net impact of real depreciation of the Brazilian real depends on which effect(s) would dominate.

\section{Data and Empirical Results}

Data were collected from the April 2010 edition of IMF's International Financial Statistics. Real GDP is measured in billion reais. The real stock price index is represented by the nominal share price divided by the consumer price index multiplied by 100 . The real exchange rate is represented by the nominal exchange rate of the reais per U.S. dollar times the price in the U.S. and divided by the price in Brazil. DEF is represented by the government deficit as a percent of nominal GDP. Using a ratio is more appropriate as the government deficit is likely to rise when more output and income are generated. The expected inflation rate is represented by the average inflation rate of the past four quarters. Real GDP in the U.S. is used as a proxy for world output. The world real interest rate is represented by the real federal funds rate in the U.S. as monetary policy in Brazil is likely to be affected by U.S. monetary policy. The sample period ranges from 1996.Q3-2009.Q3 with a total of 53 observations.

The augmented Dickey-Fuller (ADF) unit root test is presented in Table 1. As shown, except for the expected inflation rate, all other time series are non-stationary in the level form at the $5 \%$ level, and all the time series are stationary in first difference at the $5 \%$ level. 
Table 1. ADF Unit Root Test

\begin{tabular}{|l|c|c|}
\hline Variable & Level Form & First Difference \\
\hline Real GDP & 0.467 & -3.232 \\
\hline Real stock price index & -0.926 & -5.531 \\
\hline Real exchange rate & -0.811 & -6.296 \\
\hline Deficit as a percent of GDP & -2.719 & -3.974 \\
\hline Expected inflation rate & -4.372 & -3.929 \\
\hline Real GDP in the U.S. & -2.063 & -4.332 \\
\hline Real federal funds rate & -1.311 & -2.990 \\
\hline
\end{tabular}

Notes: Test statistics are estimated in the table. The critical values are $-3.560,-2.918$, and -2.567 at the $1 \%, 5 \%$, and $10 \%$ levels.

Estimated coefficients and related statistics are presented in Table 2. To determine whether the residuals may violate classical properties, several tests are performed. In the Breusch-Godfrey serial correlation LM test with a lag length of two, the test statistic of 9.52 is much greater than the critical value of 5.180 at the $1 \%$ level. Hence, the lack of serial correlation can be rejected. In the White heteroskedasticity test without cross terms, the test statistic of 1.355 is less than the critical value of 2.660 at the $1 \%$ level and 2.000 at the $5 \%$ level. Thus, the lack of heteroskedasticity cannot be rejected. In the ARCH LM test, the test statistic of 0.030 is less than the critical value of 7.080 at the $1 \%$ level and 4.000 at the $5 \%$ level. Therefore, the lack of ARCH cannot be rejected. Due to the existence of serial correlation, the GLS method is employed in order to yield consistent estimates for the standard errors and covariance.

In the estimated regression, $95.0 \%$ of the change in real GDP can be explained by the right-hand side exogenous variables that have significant coefficients. Except for the coefficient of the expected inflation rate, other coefficients are significant at the $1 \%$ level.

Real GDP in Brazil is positively associated with the real stock price index, the government deficit as percent of GDP and U.S. real output, and it is negatively affected by real depreciation of the Brazilian real and the real federal funds rate. Specifically, if the real stock price index rises by 1 , real GDP will increase 0.166 billion reais; and if the real exchange rate increases by 1 , real GDP will decline by 8.932 billion reais. The mean absolute percent error (MAPE) of $2.310 \%$ suggests that the forecast error of the regression is relatively low.

The positive significant coefficient of the real stock price index suggests that real spending in the private sector would increase in response to a higher real stock price. The negative significant coefficient of the real exchange rate indicates that real depreciation of the Brazilian real would hurt real GDP partly because the negative effect outweighs the positive effect. An expansionary fiscal policy of increased government deficit spending would raise real GDP. Increased U.S. output would increase Brazil's net exports and raise its real GDP. A 
higher real federal funds rate pursued by the Federal Reserve Bank is expected to raise Brazil's real interest rate and slow down its economic activities.

Table 2. Estimated Regression of Equilibrium Real GDP for Brazil

\begin{tabular}{|l|c|c|}
\hline Variable & Coefficient & t-Statistic \\
\hline Intercept & $96.480^{*}$ & 3.448 \\
\hline Real stock price index & $0.166^{*}$ & -3.906 \\
\hline Real exchange rate & $-8.932^{*}$ & 3.380 \\
\hline Deficit as a percent of GDP & $2.367^{*}$ & -0.622 \\
\hline Expected inflation rate & -0.663 & 7.238 \\
\hline Real GDP in the U.S. & $1.485^{*}$ & -4.677 \\
\hline Real federal funds rate & $-2.688^{*}$ & 2.161 \\
\hline AR(1) & $0.320^{* *}$ & -3.662 \\
\hline AR(2) & $-0.484^{*}$ & \\
\hline Adjusted R-squared & 0.950 & \\
\hline AIC & 6.517 & \\
\hline SC & 124.448 & \\
\hline F-statistic & $2.310 \%$ & \\
\hline MAPE & $1996 . \mathrm{Q}^{*}$ & \\
\hline Sample period & $2009 . \mathrm{Q} 3$ & \\
\hline Sample size & 5.851 & \\
\hline Notes: Figur & \\
\hline
\end{tabular}

Notes: Figures in parenthesis are t-statistics. ${ }^{*}$ and $* *$ indicate the $1 \%$ and $5 \%$ significance levels, respectively. AIC is Akaike information criterion. SC is Schwarz information criterion. MAPE is the mean absolute percent error. Serial autocorrelation is corrected with the AR(1) and $\operatorname{AR}(2)$ terms, whose coefficients are significant at the $1 \%$ or $5 \%$ level.

To determine whether the above results may be spurious, we apply the augmented Dickey-Fuller (ADF) unit root test of the regression residuals. Based on the Schwarz information criterion (SIC) with a lag length of zero, the test statistic of -6.681 is greater than 
the critical value of -2.610 in absolute values at the $1 \%$ level. Hence, these time series variables are cointegrated and have a long-term equilibrium relationship (Gujarati and Porter, 2010, pp. 383-384).

To consider a complex model, the ARCH LM test is performed. The test statistic of 0.027, which has an F distribution with the respective degrees of freedom of 1 and 50, is less than the critical value of 4.040 at the $5 \%$ level. Hence, the autoregressive conditional heteroskedasticity model is not applicable. Due to a relatively small sample size, time series techniques may not be applied properly.

\section{Summary and Conclusions}

This paper has examined the impacts of stock prices, exchange rates, and other related variables on real GDP in Brazil based on an open-economy macroeconomic model. A reduced-form equation is estimated by the GLS method to derive consistent estimates for standard errors and covariance. The sample period runs from 1996.Q3 to 2009.Q3. The estimated regression can explain approximately $95.0 \%$ of the behavior of real GDP in Brazil. Real GDP is positively affected by the real stock price index, the ratio of government deficit to nominal GDP, and U.S. output. It is also negatively associated with real depreciation and the real federal funds rate. The expected inflation rate has a negative sign but is insignificant at the $10 \%$ level.

There are several policy implications. A healthy stock market would be conducive to economic growth. Hence, the authorities may want to take measures to develop and strengthen the stock market and reduce irregularities. Although some scholars advocate real depreciation of a currency to stimulate exports, create job opportunities, and increase income, our empirical results indicate a negative impact of real depreciation of the Brazilian real on output. This is partly because the central bank of Brazil has adopted an inflation targeting policy since 1999 and is likely to raise the real interest rate to contain higher inflation due to real depreciation. Unlike some other countries, it seems that increased budget deficits as a percent of GDP would not pose a serious concern for Brazil because of its positive impact on real GDP. Brazil's economy depends on the U.S. economy and monetary policy. As the U. S. gradually recovers and as the Federal Reserve Bank continues to pursue monetary easing, it will prove beneficial to Brazil's economy.

If complete data for government debt are available, the ratio of the government budget deficit to GDP may be substituted by the ratio of government debt to GDP to determine whether similar results may be found. If time series data are available, the trade-weighted effective real exchange rate (REER) may replace the real BRL/USD exchange rate to compare the outcomes. The money market as represented by the demand for money and supply of money may also be considered.

\section{References}

Adrogué, R., Cerisola, M., \& Gelos, G. (2008). Brazil's long-term growth performance: trying to explain the puzzle. Journal of Economic Studies, 37(4), 356-376. 
Barbosa-Filho, N. H. (2008). Inflation targeting in Brazil: 1999-2006. International Review of Applied Economics, 22(2), 187-200.

Canarella, G., \& Pollard, S. K. (2007). A switching ARCH (SWARCH) model of stock market volatility: some evidence from Latin America. International Review of Economics, 54(4), 445-462.

Cerisola, M., \& Gelos, G. (2009). What drives inflation expectations in Brazil? An empirical analysis. Applied Economics, 41(10-12), 1215-1227.

Diamandis, P. F. (2008). Financial liberalization and changes in the dynamic behaviour of emerging market volatility: evidence from four Latin American equity markets. Research in International Business and Finance, 22(3), 362-377.

Gomes, F. A. R., \& Paz, L. S. (2005). Can real exchange rate devaluation improve the trade balance? The 1990-1998 Brazilian case. Applied Economics Letters, 12(9), 525-528.

Gujarati, D. N., \& Porter, D. C. (2010). Essentials of Econometrics. (4th ed.). Boston: McGraw-Hill/Irwin.

Guttler, C., Meurer, R., \& Da Silva, S. (2008). Is the Brazilian stock market efficient? Economics Bulletin, 7(1), 1-16.

Hsing, Y. (2008). A study of the J-curve for seven selected Latin American countries. Global Economy Journal, 8(4), 1-12.

International Monetary Fund. (2009). IMF Executive Board concludes Article IV consultation with Brazil. Public Information Notice (PIN) No. 09/92, [Online] Available: http://www.imf.org/external/np/sec/pn/2009/pn0992.htm (July 28, 2009)

Kalyoncu, H., Ozturk, I., Artan, S., \& Kalyoncu, K. (2009). Devaluation and trade balance in Latin American countries. Zbornik Radova Ekonomskog Fakulteta u Rijeci: Casopis za Ekonomsku Teoriju i Praksu/Proceedings of Rijeka School of Economics: Journal of Economics and Business, 27(1), 115-128.

Lyons, J. (2010). Brazil's surging currency takes stage in vote --- Next government will face pressure to act amid export-related anxiety; Goldman Dubs the real 'most overvalued. Wall Street Journal. (Eastern edition). New York, N.Y.: Oct 2, A.10.

Rathbone, J. P. (2010). Good fortune helps strengthen Brazil's economy. FT.com. London: June 28.

Romer, D. (2006). Advanced macroeconomics. ( $3^{\text {rd }}$ ed.). Boston: McGraw-Hill/Irwin.

Stewart, Alastair, \& Jeffris, Gerald (2010), Brazilian central bank raises key rate. The Wall Street Journal, [Online] Available: http://online.wsj.com/article/SB10001424052748704423504575212931696806518.html?KE YWORDS=brazil+economy (April 28, 2010)

Stewart, Alastair, Lyons, John, \& Wessel, David. (2010). Brazil's fast recovery spurs concern. 
The Wall Street [Online] Available: http://online.wsj.com/article/SB10001424052748704464704575208532345711208.html?KE YWORDS=brazil+economy (April 27, 2010)

Tabak, B. M. (2003). The random walk hypothesis and the behaviour of foreign capital portfolio flows: the Brazilian stock market case. Applied Financial Economics, 13(5), 369-378.

The Economist. (2009). Brazil takes off: now the risk for Latin America's big success story is hubris. [Online] Available: http://www.economist.com/displayStory.cfm?story_id=14845197 (November 12, 2009)

The Economist. (2009). Brazil's recovering economy: juggling technocrats and party hats. [Online] Available: http://www.economist.com/displayStory.cfm?story_id=14644374 (October 15, 2009)

The Economist. (2009). Late in, first out: Brazil is the first Latin American country to emerge from recession. [Online] Available: http://www.economist.com/displayStory.cfm?story_id=14442343 (September 12, 2009)

Worthington, A. C., \& Higgs, H. (2003). An empirical note on the random walk behaviour and market efficiency of Latin American stock markets. Empirical Economics Letters, 2(5), 183-197. 